\title{
TITLE:
}

\section{学習教材における処理流暢性が学 習者の学習プロセスに及ぼす影響}

\author{
$\operatorname{AUTHOR}(\mathrm{S}):$
}

長谷部, 育恵; 楠見, 孝

CITATION:

長谷部, 育恵 ... [ et al]. 学習教材における処理流暢性が学習者の学習プロ セスに及ぼす影響. 認知心理学研究 2020, 18(1): 1-11

ISSUE DATE:

2020-08-31

URL:

http://hdl.handle.net/2433/259356

RIGHT:

発行元の許可を得て掲載しています。 


\title{
学習教材における処理流暢性が学習者の学習プロセスに及ぼす影響1)
}

\author{
長谷部育恵・楠 見 孝 (京都大学大学院教育学研究科)
}

The influences of processing fluency in study materials on learner perceptions and performance

Ikue HASEBE and Takashi KUSUMI（Graduate School of Education, Kyoto University)

As an approach to exploring the design of effective study materials, we investigate the influences of processing fluency. Sixty-eight university-student participants received two types of study materials; one was presented in an easy-to-read font and the other was presented in a difficult-to-read font. Our comparisons of learning performance for the different materials focused on both monitoring (i.e., participant predictions of own memory scores) and control (i.e., participant allocations of study time). The participants were instructed to study the materials so that they would obtain similar scores on subsequent memory tests. The results indicated that the learners predicted lower memory scores and allocated longer study times for the materials in the difficult-to-read font compared to those in the easy-to-read font. However, no correlation was observed between study times and memory scores. Moreover, the results suggest that individual differences in terms of learner control and performance may arise from learning strategies, intrinsic motivation, and the efforts allocated to study materials.

Key words: fluency, study materials, monitoring, control, performance

本研究では, 学習教材における処理流暢性が学習者の認知・行動に及ぼす影響を検討した。大学生 $(N=68)$ が実験に参加し，流暢フォントを用いた学習課題と非流暢フォントを用いた学習教材に対して同 時進行で取り組んだ。本研究では，流暢性が学習時のモニタリング（JOL）とコントロール（学習時間の割 り当て）に及ぼす影響を見るため, 参加者に対しては学習後に実施する両課題に関するテストで，それぞれ 同程度の学習成績を残せるように学習を進めるよう求めた。 その結果, 参加者内で比較すると, 流暢フォン 卜課題に取り組んだときと比較して非流暢フォント課題に取り組んだときにはJOL の評定值は低く，かつ自 由学習時間中により多くの時間が割り当てられていた。ただし，その際学習時間と学習成績との間に相関関 係はみられなかった．補足的な分析からは，学習方略や課題に対する内発的動機づけや課題に対する努力な どによって，学習時のコントロールやパフォーマンスに個人差が生じる可能性が示唆された.

キーワード：流暢性，学習教材，モニタリング，コントロール，パフォーマンス

\section{問題と目的}

\section{学習教材の処理流暢性による学習者への影響}

学習教材をデザインする際に，どのような工夫をすれ ば効果的な教材になるだろうかと悩むことは多い. 工夫 を凝らす際の簡単かつ一般的な方法の一つとして, 教材 の文字を見やすくすることが挙げられる．手書きならば 丁寧に文字を書き，印刷ならば明瞭なフォントを利用す るといった具合にである．文字を見やすくすることで， 学習者に知覚的な快適さをもたらすことができる。その

1）本研究の一部は日本教育工学会第33回全国大会（2017 年9月）において発表された。
うえ，文字が読みやすいと学習者の動機づけを高めるこ とができる，例えば，Song \& Schwarz（2008）では運 動習慣のインストラクションや料理のレシピを見やすい フォントで読むと，記載されているアクティビティに対 して取り組みたいと感じることが示されている.

しかし, 先行研究においては学習教材における見やす さが学習者にとってのデメリットとなる可能性も示唆さ れている. まず，学習者のメ夕認知にとってのデメリッ トである．学習時に容易に知覚された学習項目に対して は，実際の記憶成績が悪いとしても，ょく記憶できたと 判断してしまうことが報告されている（Besken \& Mulligan, 2013; Carpenter, Wilford, Kornell, \& Mullaney, 2013; Kornell, Rhodes, Castel, \& Tauber, 2011; Pieger, 
Mengelkamp, \& Bannert, 2016; Rhodes \& Castel, 2009). 学習場面におけるメタ記憶, つまり記憶に関わる考えや 判断は, その後の自身の学習行動を決定づけるが, 見や すさは，不正確なメ夕記憶を引きおこすと考えられてい る(Besken \& Mulligan, 2013)。これが知覚的流暢性仮 説である（Besken \& Mulligan, 2013）.

知覚的流暢性とは, 処理流暢性, つまり「主観的な情 報処理のしやすさ」の下位概念に位置づけられる（Alter \& Oppenheimer, 2009). 処理流暢性のうち, 知覚に よってもたらされる情報処理のしやすさが知覚的流暢性 とよばれる，知覚的流暢性仮説では，知覚的流暢性が高 いと, その流暢性の高さがその後の記憶成績の高さの判 断手がかりとして捉えられてしまうと主張されている.

加えて, 流暢性は学習者の学習成績にとってのデメ リットにもなりうる。直観に反するが，一部の研究では 流暢フォントよりも非流暢フォントで学習したほうが記 憶成績が高いことが報告されている(Besken \& Mulligan, 2013;Diemand-Yauman, Oppenheimer, \& Vaughan, 2011; Eitel, Kühl, Scheiter, \& Gerjets, 2014; French et al.2013; Motyka, Suri, Grewal, \& Kohli, 2016; Sungkhasettee, Friedman, \& Castel, 2011). 例え ば, Sungkhasettee et al. (2011) では, 直立文字で書か れた単語と倒立文字で書かれた単語を混合したリストで 学習を進めた結果, 非流暢である倒立文字の単語のほう が記憶成績が高かった. Diemand-Yauman et al. (2011) では, 二つの実験を通して非流暢フォントによる成績の向 上を実証している. Study 1 は生物の授業を模しており, 大学生参加者が流暢または非流暢フォントにて架空の生 物の特徵を学習したところ, 非流暢条件のほうが成績が 高かった. Study 2 は高等学校を実験のフィールドとして おり，授業時に高校生に対して流暢または非流暢フォント で記載されたワークシートやPowerPointスライドを配布し て授業を実施したところ, 非流暢フォント教材で学んだ高 校生のほうがその後に実施したテストの成績が高かった。

学習教材においては非流暢性が学習時の認知や行動に とってのメリットとなることが複数の実験デザインに よって示されていて, これは非流暢性効果と呼ばれてい る (e.g., Kühl \& Eitel, 2016). 一方で, 近年では多くの 研究において非流暢フォントによる学習成績の向上効果が 再現されておらず（Besken \& Mulligan, 2013; Carpenter et al., 2013; Eitel et al., 2014; レビューとして, Kühl \& Eitel, 2016; Magreehan, Serra, Schwartz, \& Narciss, 2016; Pieger et al., 2016; Rhodes \& Castel, 2009; Rummer, Schweppe, \& Schwede, 2016; Yue, Bjork, \& Bjork, 2013), どのような状況下で非流暢性の効果がもたらされるのか 検討する必要がある。一つの可能性として, DiemandYauman et al. (2011) のStudy 2 に基づくと, 非流暢性 による学習成績の向上は自由に学習する時間がある状況
でみられる可能性が考えられる. 非流暢フォント課題に 取り組んだ際に, 既学習判断 (Judgement of Learning, 以後JOL）は低く評定される，つまり「学習できていな い」というメタ認知的判断がなされるが (e.g., Rhodes \& Castel, 2009), その際, 学習時間量を自由にコント ロールできる状況下ならば, 非流暢フォント課題に取り 組んだ際には流暢フォント課題よりも長く学習し, その 結果成績が向上する可能性がある.

しかし, 流暢性研究の多くにおいて, 学習成績におけ る非流暢性効果のメカニズムを明らかにするための手が かりが不十分である. 例えば, Diemand-Yauman et al.（2011）は学習成績しか測定しておらず, 学習過程 については触れていない. Zimmerman（1998）の自己 調整学習モデルによると, 学習への取り組みは「計画」, 「遂行・意志による制御」,「自己省察」の3段階の循環 によって成り立つ，学習パフォーマンス向上の有無を論 じるにあたって, 学習時間のコントロールに着目するこ とは重要である。そこで, 本研究では自由学習時間を設 けたうえで,「計画」の手がかりとなる学習状況のモ二 タリング，「遂行・意志による制御」にあたる学習時間 のコントロールの 2 点を測定する。 それにより, 流暢性 が学習時間のコントロールに及ぼす影響を検討する.

\section{実験デザイン}

本研究では実験室実験を行い, 学習教材の流暢性に よって学習者が時間配分をどのように調整するかを検討 するため, 以下のように教示を行う。第一に, 目標とす る学習成績が流暢フォント課題と非流暢フォント課題と で同じくらいになるよう, 学習時に教示を行う. 仮に非 流暢フォント課題には学習時間をかける必要があるとい う学習観があるならば, 非流暢フォント課題のほうが流 暢フォント課題よりも多くの時間がかけられるだろう. その際, 日常生活に即した学習として自然な場面設定と することで生態学的妥当性の高い実験室実験を目指すた め, 本研究ではDiemand-Yauman et al. (2011) の Study 2 に倣い, 学校現場での学習を基にした実験室実 験を実施する。そこで, 第二に, 流暢・非流暢フォント 課題の両方で $80 \%$ 以上の成績を目指すよう教示する. なぜならば, 実際の学校現場での定期テストにおいて は, 1 教科でなく複数教科の学習が並行して求められ, どの教科も良い点数が期待されるためである.

また，学習の進め方については，以下の二つの実験手 法を採用する. 第一に, 流暢フォント課題と非流暢フォ ント課題を同時進行で取り組む実験手法を採用する。通 常の家庭学習の場面では, 学習者は複数の学習課題を並 行して, 自己の判断に基づいて時間配分をしながら課題 に取り組むからである. 多くの実験では, 両フォント課 題がそれぞれ独立して, 決められた時間内において取り 組まれており, 生態学的に妥当な手法であるとはあまり 
いえない. 第二に, 実験参加者が両フォント課題に かけた学習時間を測定する. Diemand-Yauman et al. （2011）のStudy 2では, 通常の家庭学習の場面に沿っ た実験が行われ，動機づけ評定や学習成績などの指標が 測定されているが，学習時間を測定していないため, メ カニズムの検討が不十分である. Diemand-Yauman et al.（2011）のStudy 2では，授業中に実験材料である授 業資料を配布しているため, 高校生はテスト実施までの 1 週間半から 1 カ月の間, 家庭学習において自由に授業 資料に対して学習時間を割り当てることができた。ここ では非流暢性による学習成績への効果がみられたもの の, 学習時間の測定と比較は行われていない. 学習時間 を測定すれば，学習時間が不足しているというメタ認知 的判断を基にして学習時間が長く割り当てられる, とい う処理の流れが確認できる可能性がある.

以上より, 本研究では流暢・非流暢フォント課題の使 用時の学習過程を子細に検討し，そのとき両課題を同時 進行で, 同程度の高成績を目指して取り組む実験デザイ ンを採用する。これによって, 非流暢効果, すなわち非 流暢性によって学習成績が高まる現象の生起プロセスを 明らかにする。

\section{実験における仮説}

本研究では先行研究に基づき, 学習時のモニタリン グ, コントロール, パフォーマンスの3段階について以 下の仮説を立てる.

仮説 1 : 学習者のモニタリングにより, 流暢フォント課 題よりも非流暢フォント課題のほうが学習の出 来が低く評定される.

仮説 2 : 学習者のモニタリングに基づいたコントロール により, 流暢フォント課題よりも非流暢フォン 卜課題のほうが多くの学習時間が充てられる.

仮説 1 については, 前述のとおり Besken \& Mulligan （2013）などから示されている. しかし，対立する証拠 もあり (e.g., Magreehan et al., 2016), 仮説1の検討は 先行研究の再検討として位置づけられる. 仮説 2 につい ては, 学習時間の割り当てが学習課題の流暢性によって 左右されることはすでに先行研究で示されている. 例え ば, Rhodes \& Castel (2009) では, 学習対象である単 語を音声呈示したところ, 学習対象の音量が小さいとき のほうが大きいときょりも JOLが低く評定され，さらに より多くの実験参加者によって再学習の機会が求められ た. 流暢性研究に限らずより広範な先行研究に基づく と，ズレ低減モデル (discrepancy-reduction model) で 表されるように難しい課題には時間が多く割り当てられる ことや (e.g., Dunlosky \& Ariel, 2011; Thiede \& Dunlosky, 1999), 学習に自信がないほどテストに向けて多くの学 習時間が費やされること（De Bruin \& Van Gog, 2012） が示されている.
また, 本研究では, 学習時間の配分において以下の調 整変数による影響も考慮する. 1 点目は, 学習態度にま つわる個人特性で, 本研究では 4 種類用いる. 第一は梅 本・田中 (2012) の学習の取り組み（Behavioral Engagement）尺度である. 複数の学習課題に取り組む 場面において, 普段の学習の取り組みが熱心な人ほど, 「できていない」と感じた学習課題を優先させる可能性 がある. 先述のとおり, Rhodes \& Castel (2009) p Kornell et al. (2011) などの先行研究からは, 非流暢 フォント課題に対しては「できなかった」とJOL評定す ることが示されている。したがって, 学習の取り組みが 熱心な人は, 非流暢フォント課題に対して多くの時間を 充てる可能性がある.

第二は，市村・上田・楠見（2016）の内発的動機づけ 項目である. 市村他（2016）では内発的動機づけを調整 変数として見いだし, 内発的動機づけが高い場合に限っ て, 困難度が高いという情報を呈示するとその課題に注ぐ 努力量が増えると示されている.よって, 非流暢な外見が 困難度情報として働くならば, 内発的動機づけの高い人は 非流暢フォント課題に積極的に取り組むと考えられる.

第三は, 課題取り組み時の努力である. 梅本・田中 （2012）の学習の取り組み尺度では, 普段の学習の取り 組みを尋ねるが, 必ずしも実験室実験においてもその態 度であるとは限らない。そこで学習の取り組み尺度を補 う目的で, 本研究の課題取り組み時の努力を測定する.

第四は，非流暢フォント課題への対策意識である．漫 然と課題に取り組んだ場合は, 両課題に対して学習時間 に差がつかないと考えられる. なお, 課題取り組み時の 努力と非流暢フォント課題への対策意識は, 既存尺度で はなく, 本研究に適合するように新たに作成する尺度で 測定する.

2点目は読みの速さである. 非流暢フォント課題に多 く学習時間をかける必要があるという学習観だけでな く, 読みのスピードの遅さによって, 結果的に学習時間 が多くかかる可能性も想定できる。そこで, 本研究では 先行研究で用いられている読みの速さを測定する尺度を 用いて個人差を測定する。

\section{方法}

\section{実験参加者}

大学生68（男性 34, 女性34）名が参加した。平均年齢 は21.6（SD=2.7）歳であった.

\section{実験計画}

フォントの流暢性を要因とする 1 要因 2 水準（流暢・ 非流暢）の参加者内計画とした。

\section{装置}

実験用プログラムはPeirce（2007）のフリーソフト, PsychoPyを使用して作成した。 


\section{MS Pゴシック, 20pt, 黒色}

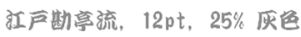

注）本誌印刷の制約上, 非流惕フォントは実際の色 $(220,220,220)$ を $(175,171,171)$ で代用している。

Figure 1. 使用した流暢・非流暢フォント.

\section{課題内容}

記憶課題は本研究オリジナルで, Diemand-Yauman et al. (2011) のStudy 1 に倣い作成した.

既有知識による影響を除くため, 架空の国であるレへ 国とネケ国の文化の特徴を記したリストを作成, 使用し た (以後, 課題 $\mathrm{A}$, 課題 $\mathrm{B}$ と表記)。課題 $\mathrm{A}$ のテーマは 「レへ国の伝統文化」, 課題 Bのテーマは「ネケ国の子ど もたちの日常」であり, 内容は独立していた。 リストは それぞれ10文で構成された（例：レへ国の南部では, 毎年7月に伝統的な祭りが開催されます). 課題 A, B の うち, 一方は流暢フォント（MS P ゴシック, $20 \mathrm{pt}$, 黒 色）で, もう一方は非流暢フォント（江戸勘亭流, 12pt, 25\% 灰色）で呈示された（Figure 1). 流暢性を フォントの種類やサイズ, 濃度で操作する点は, Diemand-Yauman et al.（2011）のStudy 1を参考にし た22. 呈示順序はカウンターバランスをとった.

\section{学習のモニタリング}

学習のモニタリングを促すため, 既学習判断 (JOL) を 実施した。1文ごとではなく，1力国分の特徴リストを見 終わるごとに10文全体に対してJOLを求めた. JOLは, 今から約 2 分後に学習課題内容に関する記述式テストを 実施することを想定させたうえで，そのテストで全体の 何\%の成績を取れるかを見積もり，10段階（1: 10\%-9: $90 \%, 10$ : 全問正解) でキー押下にて回答するよう求めた.

\section{学習のコントロール}

学習のコントロールの実態をみるため, 自由学習時間 を設けた，自由学習時間中は，キーボードのFキーと Jキーを押すことでフォントの異なる 2 課題のうちどち らか一方を PC画面上に呈示できた。自由学習時間の枠 内で，どちらの課題にどれだけ時間を割り当てるかは参 加者に一任された．ただし，いずれの学習も行っていな いときには，Spaceキーを押すことで休䪹画面を表示す るよう求めた.

実験用プログラムの設定により，いつF・J・Space キーが押されたかのログが残され，参加者がどのタイミ

2) なお, 潜在学習において語義とフォントの視覚表現が 一致する場合, 記憶成績が高くなるという知見がある が (宮代・原田, 2016), 本研究で行うのは顕在学習な ので, フォントの種類による潜在的影響は相対的に小 さいと考えられる.
ングで課題 $\mathrm{A}$, 課題 $\mathrm{B}$ ，もしくは休秝画面を画面上に呈示 させたかが記録された。これによって, 二つの学習課題 に対してそれぞれどれだけの時間が費やされたかを算出 できるようにした。

なお，自由学習時間の前にはテストに対する目標を統 制した、第一に, テスト形式は記述式であると予告し た. 第二に, 二つのテストの合計点を高めるのではな く，両テストにおいてバランスよく得点することが必要 であると伝えた。

\section{再生テストの構成}

再生テストは一問一答式であった，学習課題の各文か ら一問ずつ出題し（例：レへ国の伝統的な祭りは, どの 地方で開催されますか), 計 10 問 $\times 2$ 力国分とした。 Diemand-Yauman et al. (2011) と同様に再生のみを求 め, 推論は必要としない課題であった.

フォントにはMS明朝が用いられた。

\section{実際の読みの速さの測定}

RAN (Rapid Automatized Naming) 課 題とWord Chains課題を用いた. RANは呈示された色や物体, 数 字, 文字の名前を素早く口頭で回答する能力測定であると 定義されている (Papadopoulos, Spanoudis, \& Georgiou, 2016). RAN課題は, Papadopoulos et al. (2016) を参考 に作成された，本研究では，梅本・森川・伊吹（1955） に揭載されている2字の無意味綴りのカタカナ5項目 （例：ルエ・ロュ・ツソ・ネュ・ヘネ） $\times 4$ 行の計 20 問 で構成した．参加者は, 「1語ずつ覚えるつもりで, 自 分のペースで」読みあげるよう教示を受けるマイペース RAN課題と先行研究どおりに「できるだけ早く, 正確 に」読みあげるよう教示を受ける RAN 課題の 2 種類に 取り組んだ. Word Chains課題も Papadopoulos et al.（2016）を参考に作成された。 カタカナで表記され た三つの日常語を間隔なく横に並べ（例：スズメックエ ケンダマ), それを1画面上で 4 行呈示した。参加者は 各行を構成する三つの日常語を同定し, 区切れを報告し た(例：スズメとックエとケンダマ)。回答の制限時間 は $4 \mathrm{~s} て ゙, R A N$ 課題と同様に回答は口頭で実施した.

RAN課題, Word Chains 課題ともに, 2 画面作成し, 一方を流暢フォント，もう一方を非流暢フォントで呈示 した。呈示順はカウンターバランスをとった。

\section{個人特性項目}

梅本・田中（2012）の学習の取り組み尺度（4項目, 例：私は集中して授業を受けている), 市村他（2016） でElliot \& Harackiewicz（1994）の尺度を翻訳して作 成・使用された内発的動機づけ項目（5項目, 例：とて も面白く取り組める), 本研究で新たに作成した課題取 り組み時の努力 (2 項目, 例 : 課題に一生懸命取り組ん だ・できるだけ良い点をとろうと努力した , 非流暢 フォント課題への対策意識（2項目, 例：読みにくい課 
長谷部・楠見 : 学習教材における処理流暢性が学習者の学習プロセスに及ぼす影響

題には，時間をかけて取り組もうと考えていた・読みに くい課題には時間をかける必要があると考えた）を尋ね る項目を，個人特性を捉える尺度として使用した ${ }^{3)}$. た だし, 内発的動機づけは実際に課題に取り組んでいくう ちに変化する可能性もあるので, 2 時点で評定を求め た。課題前には「とても面白く取り組める」, 課題後に は課題中を振り返る形で,「とても面白く取り組めた」 に対して評定した。いずれの尺度に対しても，5件法 (1: あてはまらない-5: あてはまる) での回答を求めた.

\section{手続き}

実験室で個別に実験を実施した。初めに, 実験の概要 を説明のうえで, 内発的動機づけ尺度への回答を求め た ${ }^{4)}$. その後学習課題と JOLを実施した。参加者はPC 画面上に呈示される架空の国の文化に関する情報を, $30 \mathrm{~s}$ 間ですべて覚えるよう学習を行った。その直後に 「約2分後に，この国の文化に関する記述テストを実施 すると仮定します。あなたは全体の何％の成績を取れる と思いますか」という教示の下, 参加者はJOLを回答し た.これを2学習課題分行った. 課題実施順はカウン ターバランスをとった。

次に「再学習時間を設けます」と伝え，180 sの自由 学習時間を設けた. $180 \mathrm{~s}$ の間はキー押下によって何度 でも画面を切り替えることができ, 流暢フォント課題と 非流暢フォント課題の二つを自由に学習することができ た。ただし，両課題を並べて画面上に表示させることは できない仕組みにした．自由学習時間中はPCの画面横に タイマーを設置して残り時間が見えるようにし, 学習時 間の配分を調整しやすい環境にした，自由学習時間の開 始前には再生テストの実施を予告した。その際, 学習時 の認識を統一するため,「再学習後のテストは記述式です」 と教示した. 加えて, 両課題の価值は同等であると方向 ゔけて, 得点が同じになるような学習時間の調整を促す ために,「2種類の国の文化を比較して, より得点の低い 方があなたの成績となります」,「正答率 $80 \%$ 以上を目指 し，時間配分を調整してください」と教示した． $60 \mathrm{~s}$ の百 マス計算課題を挟んだ後, 残り時間が見えるようタイ マーを置いた状態で再生テストを $180 \mathrm{~s}$ で実施した。

一連の学習・テスト試行の後は $60 \mathrm{~s}$ ほどの休憩を挟ん だ後に, RAN課題とWord Chains課題を実施した。IC レコーダを用いて音読時の音声を録音した5).

最後に, 各質問項目に対する回答を求めた。初めに, 学習で用いた二つの記憶課題を呈示したうえで,「上の 画像の文字は, 読みやすい」に対して主観的な読みの流 暢性を 5 件法（1: あてはまらない-5: あてはまる）で評

3）ただし, 学習への取り組み以外の尺度は, 68名中後半 の34名が回答した.

4）68名のうち前半 34 名は内発的動機づけ尺度に回答しな かった.
定するよう求めた。その後, 個人特性を測定する各尺度 に対して回答を求めた6). 回答後は, 実験に対する感想 や質問を受け付け，謝礼を渡して実験を終了した。

\section{結果と考察}

流暢性評定において，流暢フォントよりも非流暢フォ ントで流暢性を高く評定した参加者1名のデータは除い た。流暢フォントのほうが読みやすい, もしくは読みや すさは同程度であると評定した参加者 67 名の記述統計 量と条件間の $t$ 検定の結果, 効果量, および相関を Table 1 に示す.

流暢性の操作チェックのため, 流暢性評定について対 応のある $t$ 検定を行ったところ, 流暢フォントよりも非 流暢フォントのほうが流暢性評定が有意に低かった (Table 1). よって, 実験操作は成功し, 本研究で用い た2種類のフォントはそれぞれ適切な材料であったとい える.ささら, 学習成績の操作チェックのため, 学習成 績において対応のある $t$ 検定を行ったところ, 両課題と も有意な差はみられなかった（Table 1)。よって，実験 操作は実験者の意図どおりで, 参加者は両課題で同じく らいの学習成績をとろうとコントロールしたといえる.

なお, JOL評定の際の課題実施順序による主効果は, JOL・学習時間・学習成績においてみられないことが確 認された（Table 2)。また，対応のある $t$ 検定では有意 差がみられなかったが, 両課題の学習成績を散布図に表 すと, 流暢フォント課題で高い参加者, 非流暢フォント 課題で高い参加者がおり，ばらつきを生んでいたことが 示唆された（Figure 2)。これにより個人特性を検討す る必要性が確認された。

\section{JOL 評定値の比較}

Table 1では, 各変数について流暢・非流暢フォント 条件間を比較するため, 対応のある $t$ 検定を実施した. JOL の評定值について $t$ 検定を行った結果, 参加者は非 流暢フォント課題のほうが流暢フォント課題よりも冒頭 $30 \mathrm{~s}$ 学習の後に学習の出来を有意に低く見積もってい た. よって, 仮説 1 は支持された.

なお, JOL評定の際の課題実施順序を要因に加えた 2 要因混合計画の分散分析の結果, 有意傾向の交互作用 がみられた（Table 2)。下位検定の結果，単純主効果が 確認され, JOL評定実施順が流暢・非流暢フォント課題 でもその逆順でも非流暢フォント課題のほうがJOL 評定 が低いことに加え $(F s(1,65)=52.17,10.71, p s<.01)$, 非流暢・流暢フォント課題の順でJOL評定した場合は その逆順よりも非流暢フォント課題の JOL評定が高い

5）RAN課題, Word Chains課題ともに本番前に課題練習 試行を挟み, 事前に疑問点を解消できるようにした。

6） 68 名のうち前半 34 名は, 梅本・田中（2012）の学習の 取り組み尺度のみに回答した。 
認知心理学研究 第 18 巻第 1 号

Table 1

流暢・非流暢条件の各変数の平均 $\cdot S D$ と相関 $(N=67)$

（相関係数表・右上：流暢条件，左下：非流暢条件）

\begin{tabular}{|c|c|c|c|c|c|c|c|c|c|c|c|c|c|}
\hline \multirow{2}{*}{ 変数 } & \multicolumn{2}{|c|}{ 流暢 } & \multicolumn{2}{|c|}{ 非流暢 } & \multirow{2}{*}{$t$} & \multirow{2}{*}{$d$} & \multicolumn{7}{|c|}{ 相関係数 } \\
\hline & $M$ & $S D$ & $M$ & $S D$ & & & 1 & 2 & 3 & 4 & 5 & 6 & 7 \\
\hline 操作チェック & & & & & & & & & & & & & \\
\hline $\begin{array}{l}1 \text { 流暢性評定（1-5） } \\
\text { モニタリング }\end{array}$ & 4.63 & 0.57 & 1.27 & 0.64 & $32.44 * * *$ & 5.56 & - & .11 & .06 & -.08 & -.08 & -.18 & $-.26^{*}$ \\
\hline $\begin{array}{l}2 \text { JOL }(1-10) \\
\text { コントロール }\end{array}$ & 4.58 & 1.58 & 3.54 & 1.42 & $6.92^{* * *}$ & 0.70 & -.05 & 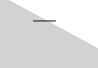 & .05 & $.34 * *$ & .01 & .11 & .17 \\
\hline $\begin{array}{l}3 \text { 学習時間 }(0-180 \mathrm{~s}) \\
\text { パフォーマンス }\end{array}$ & 76.95 & 16.62 & 96.05 & 17.28 & $5.00^{* * *}$ & 1.14 & .07 & $-.24^{*}$ & & .08 & -.02 & .13 & .01 \\
\hline $\begin{array}{l}4 \text { 学習成績（0-10） } \\
\text { 読みの速さ }\end{array}$ & 6.51 & 2.17 & 6.58 & 2.20 & 0.25 & 0.03 & .16 & $.34^{* *}$ & -.13 & - & .11 & $.32 * *$ & .18 \\
\hline 5 マイペースRAN & 0.88 & 0.26 & 0.88 & 0.26 & 0.25 & 0.01 & .03 & .18 & .07 & -.05 & - & $.35 * *$ & .16 \\
\hline 6 RAN & 1.89 & 0.39 & 1.85 & 0.37 & 1.25 & 0.10 & .08 & $.26^{*}$ & -.04 & .16 & $.30^{*}$ & - & $.61^{* * *}$ \\
\hline 7 Word Chains & 7.07 & 1.85 & 6.00 & 1.82 & $5.18^{* * *}$ & 0.59 & .10 & .16 & $-.27^{*}$ & .05 & .08 & $.28^{*}$ & - \\
\hline
\end{tabular}

$* p<.05, * * p<.01, * * * p<.001$

注） $\mathrm{RAN}=$ Rapid Automatized Naming 課題

Table 2

JOL 実施順序を要因に加えた際の各変数の平均・SD

\begin{tabular}{|c|c|c|c|c|c|c|c|c|c|c|c|c|}
\hline \multirow{2}{*}{ 変数 } & \multicolumn{3}{|c|}{ 流暢フォント } & \multicolumn{3}{|c|}{ 非流暢フォント } & \multicolumn{2}{|c|}{ フォントの流暢性 } & \multicolumn{2}{|c|}{ 実施順序 } & \multicolumn{2}{|c|}{ 交互作用 } \\
\hline & $M$ & $S D$ & $n$ & $M$ & $S D$ & $n$ & F值 & $(d f)$ & $F$ 値 & $(d f)$ & $F$ 值 & $(d f)$ \\
\hline \multicolumn{13}{|l|}{ モニタリング（JOL） } \\
\hline $\begin{array}{l}\text { 流暢・非流暢（0-10） } \\
\text { 非流暢・流暢（0-10） }\end{array}$ & $\begin{array}{l}4.58 \\
4.59\end{array}$ & $\begin{array}{l}1.48 \\
1.69\end{array}$ & $\begin{array}{l}33 \\
34\end{array}$ & $\begin{array}{l}3.21 \\
3.85\end{array}$ & $\begin{array}{l}1.41 \\
1.37\end{array}$ & $\begin{array}{l}33 \\
34\end{array}$ & $50.88 * * *$ & $(1,65)$ & 0.96 & $(1,65)$ & $4.56^{*}$ & $(1,65)$ \\
\hline \multicolumn{13}{|l|}{ コントロール（学習時間） } \\
\hline $\begin{array}{l}\text { 流暢・非流暢（0-180s） } \\
\text { 非流暢・流暢（0-180s） }\end{array}$ & $\begin{array}{l}76.39 \\
77.49\end{array}$ & $\begin{array}{l}15.60 \\
17.76\end{array}$ & $\begin{array}{l}33 \\
34\end{array}$ & $\begin{array}{l}95.35 \\
96.73\end{array}$ & $\begin{array}{l}19.09 \\
15.58\end{array}$ & $\begin{array}{l}33 \\
34\end{array}$ & $24.62 * * *$ & $(1,65)$ & 0.60 & $(1,65)$ & 0.00 & $(1,65)$ \\
\hline \multicolumn{13}{|l|}{$\begin{array}{l}\text { パフォーマンス（学習成績） } \\
\text { JOL実施順序 }\end{array}$} \\
\hline $\begin{array}{l}\text { 流暢・非流暢（0-10） } \\
\text { 非流暢・流暢（0-10） }\end{array}$ & $\begin{array}{l}6.67 \\
6.35\end{array}$ & $\begin{array}{l}2.37 \\
1.98\end{array}$ & $\begin{array}{l}33 \\
34\end{array}$ & $\begin{array}{l}6.33 \\
6.82\end{array}$ & $\begin{array}{l}2.12 \\
2.28\end{array}$ & $\begin{array}{l}33 \\
34\end{array}$ & 0.06 & $(1,65)$ & 0.04 & $(1,65)$ & 1.89 & $(1,65)$ \\
\hline
\end{tabular}

${ }^{*} p<.05, * * * p<.001$

傾向にあることも示された $(F(1,65)=3.55, p<.10)$. よって, 非流暢フォント課題の JOL評定は低く，特に 流暢フォント課題と比較して評価されるとより低い評価 になることが示唆された。

\section{学習時間の比較}

学習時間の割り当てについて対応のある $t$ 検定を行っ た結果 ${ }^{7)}$, 参加者は流暢フォント課題よりも非流暢フォ ント課題に対して，有意に多くの学習時間を充てていた

(Table 1).よって，仮説 2 も支持された.

非流暢フォント条件にて学習時間が長く充てられるの は，流暢条件よりも非流暢条件のほうが再学習の機会の
ニーズが高かったRhodes \& Castel (2009) の結果と 一致している.ただし, 学習時間の長さの結果について 一致しない先行研究もある. Pieger, Mengelkamp, \& Bannert（2017）では，学習時間がフォントの流暢性に かかわらず同程度であった。これは，本研究が学習者に 対して学習の戦略性を意識させたことによるものだと推 測される．本研究では参加者の前にタイマーを置いたう えで, $180 \mathrm{~s}$ の限られた時間で良い成績を収めるよう求 めた。また, Rhodes \& Castel (2009) では, 学習者に JOL評定つまり学習のモニタリングをさせたうえで, 再 学習の機会を求めるかどうかを評定するよう求めてい 
長谷部・楠見 : 学習教材における処理流暢性が学習者の学習プロセスに及ぼす影響

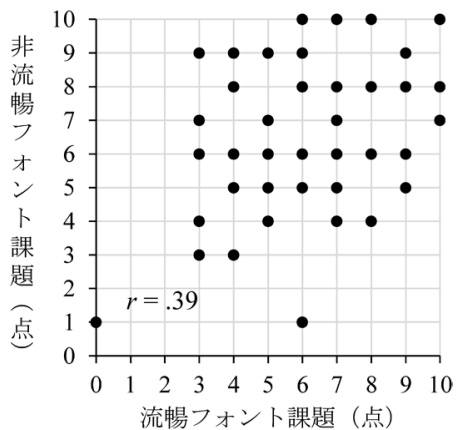

Figure 2. 流暢・非流暢フォント課題の学習成績の 散布図.

る. 一方で Pieger et al. (2017) では，学習できたと判 断した時点で合図するょう求めている. 本研究や Rhodes \& Castel (2009) と比べて, Pieger et al.（2017) は直観的な判断に基づくデータとなっている. 加えて, Pieger et al. (2017) では, 実験参加者が学習中にメモ を取ることが許されていて, 両フォント課題だけでなく 参加者自身が作成したメモを見ながらの学習が行われて いたと考えられるので, 流暢性の操作が弱まっていたと いう見方もとれる。

なお，ほかにも学習のコントロールの指標として，自 由学習時間開始後にどちらの課題から着手したかという 点が挙げられるが, 参加者 67 名中5名を除く全員が $\mathrm{F}$ キーによって画面表示される課題, つまり $30 \mathrm{~s}$ 学習や JOL評定を先に実施したフォント課題から始めていた. よって, 最初に取り組む課題は操作性や実験手続きの流 れに影響されており，学習のコントロールの指標にする には適切でないといえる。

\section{読みの速さに基づいた学習時間の検討}

補足的な分析として，流暢・非流暢フォント使用時の 読みの速さを確認するため, Papadopoulos et al.（2016） に倣ってRAN課題得点, マイペースRAN課題得点, Word Chains課題得点を算出した. RAN課題得点, マ イペースRAN課題得点について対応のある $t$ 検定を 行った結果, 双方において流暢性の主効果は有意でな く, 得点は同程度であった（Table 1)。よって, 非流暢 フォント課題の学習時間が長かったのは知覚に時間を要 した結果とは必ずしもいえないだろう。参加者は, RAN課題実施までに非流暢フォントを $30 \mathrm{~s}$ 学習と自由 学習時間において見ていて, 知覚的プライミングの効果 によってすでに流暢な処理が可能になっていたと考えら れる. 同様に, 自由学習時間の段階でもすでに流暢な処

7）学習時間データを常に和が一定になるイプサティブ データであるとみなしても, 南風原・平井・杉澤 （2009）に基づけば $t$ 検定を用いることに問題はないと いえる.
理ができるようになっていた可能性がある。したがっ て, 非流暢フォント課題において学習時間が長く配分さ れたのは, 処理速度の遅さというょりも, むしろ読みに くさの主観によるものであると解釈することができる. 一方で, Word Chains課題得点については, 対応のあ る $t$ 検定を行った結果, 流暢フォントよりも非流暢フォン トのほうが得点が低かった (Table 1). Word Chains課題 では, わずか $4 \mathrm{~s}$ の間にカタカナの文字列から単語を探し て回答することを求めたため, 大きさやコントラストの低 さなどによる妨害を乗り越えて瞬時にフォントを知覚す る能力が必要であった。そのため, フォントを瞬時に知 覚できず，慣れない文字の読みに切り替えることができ ない参加者は学習時間が長くかかった可能性がある.

また, Word Chains課題の特徴として, 言語処理を要 する点が挙げられる。 そのため, 知覚的な非流暢性その ものが原因というょりも，知覚的な非流暢性が言語処理 などのより高次な処理の流暢性に影響を及ぼした結果, 学習時間が長くなったと解釈することができると考える.

\section{学習時のコントロールとパフォーマンスの関連}

学習過程に着目するため, 相関分析 (Table 1) から コントロールとパフォーマンスとの関連をみると, 学習 時間の割り当てと学習成績との間には, 流暢条件では相 関がみられず $(r=.08)$, 非流暢条件でも有意な相関は みられなかった $(r=-.13)$. 学習者は学習時に意図的 に方略を選択する（Marton \& Saljo, 2005)。 そこで, 学 習者には, 質の悪い学習をする, すなわち漫然と学習に 時間をかけてしまうタイプと，質の良い学習をする，す なわち深く分析的な処理をして学習に時間をかけること のできるタイプがいると考える，仮に非流暢効果がない とすれば, 本研究の両条件において学習時間のコント ロールとパフォーマンスとの間に相関がみられなかった （両条件それぞれ $r s=.08,-.13 ）$ 原因は，上記 2 タイプ の学習者の存在だと考えられる。また，仮に非流暢効果 があるとすれば, 非流暢フォント条件では後者のタイプ が引き出されると考えられるため, 非流暢フォント条件 で無相関だった原因は他にあると考えられる。例えば, 流暢フォント課題に長く時間を充てることで非流暢フォ ント課題の成績を高めていた可能性がある，実験終了後 に行ったヒアリングでは，本研究で用いた二つの学習課 題が類似していたため, 流暢フォント課題を活用して非 流暢フォント課題を学習するという方略（例：数字情報 同士を両課題同時に記憶する）をとったことが参加者 2名から報告された。つまり, 非流暢フォント課題自体 に時間をかけるのではなく, 流暢フォント課題を応用す ることで学習を補っていたと推測される。このように, 学習方略の多様性によって生ずる個人差が原因で, Diemand-Yauman et al.（2011）での非流暢性効果の再 現を試みた多くの先行研究が再現に失敗していた 
（Bjork \& Yue, 2016）のだと推測される.

\section{非流暢性フォントと個人特性との関連}

最後に, どのような特徵をもつ人が非流暢フォントで 成績を高めるか, またそのときの学習時間の割り当てを 検討した. 個人差検討用の尺度の信頼性については, 課 題前の内発的動機づけ $(\alpha=.83 ; M=3.38, S D=0.75)$, 課題中の内発的動機づけ $(\alpha=.90 ; M=3.69, S D=0.80)$, 学習への取りみ $(N=67, \alpha=.88 ; M=2.70, S D=0.56)$, 課題取り組み時の努力 $(\alpha=.77 ; M=4.38, S D=0.53)$, 非 流暢フォント課題への対策意識 $(\alpha=.76 ; M=3.78$, $S D=0.94 ）$ で十分な高さが確認された. Table 3 にコント ロール・パフォーマンスと個人特性変数との相関を示す.

相関分析の結果 (Table 3), 非流暢フォント条件の学 習成績と内発的動機づけとの間に弱い正の相関が $(r=.30)$, 課題中の内発的動機づけとの間に中程度の正 の相関がみられた $(r=.47)$. 課題前より課題中のほう が相関が強く, 学習前というょり学習中に面白いと感じ ることが学習成績における非流暢性効果にとって重要だ といえる。他方, 流暢フォント課題の学習成績は, 課題 前や課題中の内発的動機づけとの相関がみられなかった $(r \mathrm{~s}=-.08, .10)$. また, 課題取り組み時の努力と非流 暢フォント条件の学習成績との間に弱い正の相関がみら れ $(r=.29)$, 流暢フォント条件の学習成績との間には 相関がみられなかった $(r=-.13)$. その他の個人特性 は学習成績との間に相関がみられなかった. よって, 内 発的動機づけの高い学習者や学習課題に努力を注げる学 習者であるほど非流暢フォント課題のパフォーマンスが 高いことが示された.

課題中の内発的動機づけは非流暢フォント課題の学習 時間の割り当てとの間に弱い負の相関（秒換算・割合換 算それぞれ $r s=-.19,-.35)$ をもっていたが, 前述の とおり非流暢フォント条件の学習成績との間には正の相
関 $(r=.47)$ がみられた.つまり, 課題中の内発的動機 づけが高いと流暢フォント課題に多くの割合の時間を充 て（秒換算・割合換算それぞれ $r \mathrm{~s}=.41, .35 ）$, なおかつ 非流暢フォント課題の成績が高いという関連がみられ た. 非流暢フォント課題において学習時間と成績が負の 相関関係にあるいう結果は, 直観に反する. 加えて, 学 習時間量のみに言及するならば，市村他（2016）では, 内発的動機づけの高い人は, 課題困難度が高いという情 報が呈示された状況にて課題に対する努力量が大きいこ とが示されている. フォントの流暢性が課題の困難度情 報として働いているとすれば, 内発的動機づけの高い学 習者は, 非流暢フォントを用いた学習課題に対して粘り 強く取り組むと考えられるので, 本研究では市村他 （2016）とは異なる結果が得られたといえる。なお，解 釈の仕方として最近接学習領域 (region-of-proximallearning) のフレームワーク（レビューとして Metcalfe, 2009）を採用するならば，容易な課題に取り組んでか ら困難な課題に取り組んだとして説明がつくが, 本研究 では自由学習時間前に学習課題に対してバランスよく得 点するよう教示をしている.つまり, 最近接学習領域と は反対の意味をもつ, ズレ低減モデル（discrepancyreduction model）を促す手続きをとっている.

上記の一貫しない結果に対する解釈として, まず, 「学習時のコントロールとパフォーマンスの関連」の項 で述べた, 流暢フォント課題を活用して非流暢フォント 課題に取り組むという方略が考えられる。 また，市村他 （2016）での課題に対する粘り強さを高パフォーマンス のための努力量とみなすと, 本研究では流暢フォント課 題の活用を通して非流暢フォント課題の記憶成績を高め ようと努力していたので, 市村他（2016）の結果と 一貫しているといえる. 実験終了後に行ったヒアリング によって2名の参加者がとっていたと明らかになった学

Table 3

コントロール・パフォーマンスと個人特性との相関

\begin{tabular}{|c|c|c|c|c|c|}
\hline 変数 & 学習への取り組み & 内発的動機づけ & $\begin{array}{c}\text { 内発的動機づけ } \\
\text { (課題中) }\end{array}$ & $\begin{array}{c}\text { 課題取り組み時の } \\
\text { 努力 }\end{array}$ & $\begin{array}{c}\text { 非流暢フォント } \\
\text { 対策意識 }\end{array}$ \\
\hline \multicolumn{6}{|l|}{ 流暢フォント条件 } \\
\hline 学習時間（0-180s） & .09 & .20 & $.41^{*}$ & -.11 & $-.32^{\dagger}$ \\
\hline 学習時間（0-1） & .10 & .23 & $.35 *$ & -.09 & $-.33^{\dagger}$ \\
\hline 学習成績 $(0-10)$ & -.08 & -.08 & .10 & -.13 & .08 \\
\hline \multicolumn{6}{|l|}{ 非流暢フォント条件 } \\
\hline 学習時間（0-180s） & -.11 & -.24 & -.19 & .04 & $.29^{\dagger}$ \\
\hline 学習時間 $(0-1)$ & -.10 & -.23 & $-.35^{*}$ & .09 & $.33^{\dagger}$ \\
\hline 学習成績（0-10） & .07 & $.30^{\dagger}$ & $.47 * *$ & $.29^{\dagger}$ & -.27 \\
\hline
\end{tabular}

${ }^{\dagger} p<.10,{ }^{*} p<.05, * * p<.01$

「学習への取り組み」は $N=67$, それ以外は $N=34$.

注）「学習時間 (0-1)」とは, 課題 $\mathrm{A} ・ \mathrm{~B}$ の学習時間の和を分母, 流暢フォント課題, または非流暢フォント課題の取り組み時間を分 子として算出した, 学習時間の割合である. 
長谷部・楠見 : 学習教材における処理流暢性が学習者の学習プロセスに及ぼす影響

習方略, つまり流暢フォント課題を活用して非流暢フォ ント課題に取り組むという方略から着想を得ると, 非流 暢フォントで書かれた学習教材は, 学習者の適応的な学 習行動によって補われるものの, 学習者にとっては使用 しづらかったことが推測される.

内発的動機づけ以外の個人特性については, 課題取り 組み時の努力も非流暢フォント課題の学習成績と相関が みられたが $(r=.29)$, 学習時間とは無相関であった (秒換算・割合換算それぞれ $r s=.04, .09)$. 反対に, 非 流暢フォント課題対策意識は非流暢フォント課題におけ る学習時間の割り当てとの間に弱い正の相関（秒換算 割合換算それぞれ $r s=.29, .33 ）$ がみられたが, 学習成 績との間にみられたのは弱い負の相関であり, 正の相関 はみられなかった $(r=-.27)$ ，学習時間が学習成績に 比例するという考え方は物量主義と呼ばれるが（市川, 1993), 物量主義の学習者には学習成績における非流暢 性効果は得られないといえる。

\section{まと め}

本研究では, 非流暢フォント課題を流暢フォント課題 と同時進行で取り組んだ際のモニタリング, コントロー ル, パフォーマンスとの関連を検討した。本研究は, Diemand-Yauman et al. (2011) の実験デザインを一部 踏襲しつつ，（a）新たに学習時間を測定して学習過程に 着目した点，（b）日常の学習場面に則して流暢・非流 暢フォント課題を同時進行で取り組むよう求めた点, （c）流暢性を参加者内要因として個人差を捉えょうとし た点で, 方法論的に新規性がある。学術的には, 非流暢 フォント課題に取り組む際の学習者のモニタリング，コ ントロールをデータとして取得し, 学習成績をそろえる よう教示された状況で, 流暢性が学習者のコントロール にどのような影響を及ぼすのかを検討した点で意義があ ると考える。

Diemand-Yauman et al. (2011) のStudy 2が実験課 題を他の課題と同時進行で取り組みうる状況であったこ とを受けて, 本研究では流暢・非流暢フォント課題への 取り組みを同時進行にする手続きをとった。それによ り, 流暢・非流暢フォント間でどのように学習時間がコ ントロールされ，パフォーマンスに影響を与えるのかを 検討する狙いがあった。 そこで, 次に参加者内での流 暢・非流暢フォント使用時の比較を通した考察をする。

\section{本研究で明らかになったこと}

Table 1により，(i）モニタリングの指標であるJOL は非流暢フォント課題のほうが低く評定されたことか ら,「学習者のモニタリングにより, 流暢フォント課題 よりも非流暢フォント課題のほうが学習の出来が低く評 定される」(仮説1）ことが示された。ささらに，(ii）コ ントロールの指標である学習時間の割り当てについて
は, 非流暢フォント課題のほうが長く時間が充てられて いたことから,「学習者のモニタリングに基づいたコン トロールにより, 流暢フォント課題よりも非流暢フォン 卜課題のほうが多くの学習時間が充てられる」(仮説2) ことが示された。学習者は, 非流暢フォントで流暢フォ ントと同程度の学習成績を収めるために, 流暢フォント 課題よりも多くの時間を費やす必要があるという学習観 をもっている可能性が示唆された。ただし, 両フォント 課題とも学習時間と学習成績との間に相関関係はみられ なかった。そこで, 学習に関わる個人特性や学習時間の 内訳, つまり学習方略を, 次のとおり検討した.

個人特性が流暢性と学習との関係にどのような影響を 及ぼすのかを検討した結果, 第一に, 内発的動機づけの 高い人ほど非流暢フォント課題の得点が高かった。そのの 際, 非流暢フォント課題ではなく, 流暢フォント課題に 時間を充てることで非流暢フォント課題の学習成績を伸 ばしていた，参加者へのヒアリングからは，一部の参加 者は読みやすい流暢フォント課題を活用して, 読みにく い非流暢フォント課題に取り組んでいたことがうかがえ る.これは, パフォーマンスは学習時間の長さというよ りも学習方略によって左右されることを示唆している. 非流暢フォント課題の学習時間と個人特性との関係性を 整理すると, 読みにくい学習教材には時間をかける必要 があるという学習観, 言い換えると物量主義（市川, 1993）をもつ人は，その学習観に基づいて多くの学習 時間を充て, 学習課題を内発的動機づけに基づいて取り 組んでいた人は, 非流暢フォント課題だけでなく, それ 以外のリソース（例：見やすい別の類似教材）も併用し て良い成績をとろうと工夫するということが窥えた。第 二に, 本研究の学習課題に努力を注いだ人ほど, 非流暢 フォント課題で学習成績が高かった。 以上を踏まえる と, 学習成績における非流暢性効果は限定的であり, 例 えば内発的動機づけの高い学習者や課題に対して努力を 注げる学習者にもたらされる可能性が示唆された。

\section{学習教材の流暢性研究や教育実践への寄与}

学習教材の処理流暢性をめぐる研究への寄与をまとめ る. 前項の（i）によって, 流暢条件よりも非流暢条件 にてJOL評定が低くなることがより一層頑健な知見と して示された。また, 本研究では学習者の内的な学習方 略までは可視化できていないが, 前項の（ii）は，従来 考えられてきた非流暢性効果のメカニズム，つまり非流 暢性によって深い処理水準, すなわち意味的処理が引き 出されるという説明を否定するものではないだろう。

教育実践への寄与は2点ある. 第一に，(ii）によって, 非流暢フォント課題には学習時間が多く充てられるので, ほかの学習課題に充てる時間が相対的に削られてしまう 可能性が示された. Diemand-Yauman et al. (2011) の Study 2では学習成績にて非流暢性効果がみられたが, 
本研究の結果に基づけば, 教育実践において非流暢フォ ントを活用することは好ましいとは言いがたいだろう。 ただし，本研究の知見を応用するならば，教授者が学習 者にとりわけ重点的に学習してほしいと望む箇所を非流 暢にすればよいといえる，そうすれば，自然と非流暢箇 所に注目が促され, 学習時間が長く充てられるだろう.

第二に, 個人特性との関連については, 流暢フォント 課題の学習成績は個人の内発的動機づけや課題への努力 の注ぎ具合に影響されないのに対し，非流暢フォント課 題に関しては影響されるという関係性が示された．学習 成績における非流暢性効果があまり再現されていないう え (Bjork \& Yue, 2016), 内発的動機づけの低い人や課 題にあまり努力を注がない人にネガティブな影響を及ぼ すならば，少なくとも個人差の大きい教育現場では，非 流暢フォントを用いた学習教材を一律に使用することは 適切であるとはいえないだろう。

\section{本研究の限界点と今後の課題}

本研究の限界を 4 点挙げる. 1 点目は自由学習時間枠 による限界である. 本研究では両フォント課題の自由学 習時間が 180 sであったが, 非流暢フォントがもたらす と考えられている深い処理を実施するには, $180 \mathrm{~s}$ は短 すぎた可能性がある。また，流暢・非流暢フォント課題 を, $180 \mathrm{~s}$ という短時間で交互に取り組むことは, 日常 の学習場面と比較したときに課題状況として妥当であっ たとは言い難い. 非流暢フォントの長所が発揮されるよ うに学習時間を長くし, 非流暢性効果の再現を試みるこ とが今後の課題といえる.

2 点目は学習時間の設定による限界である. 本研究で は非流暢フォント課題に学習時間が長く充てられたが, 成績は両フォント課題間で同程度であった。しかし, 学 習時間を充てた結果, 非流暢フォント課題の成績が流暢 フォント課題の成績に追いついたのか, それとも非流暢 フォント課題にて学習時間が充てられなかったとしても 両フォント条件間で学習成績の差がなかったのかは不明 である．以上を明らかにするために，本研究で报った両 フォント課題間で, 学習時間を統制したうえで学習成績 を比較することが今後の課題といえる.

3点目はテスト時のフォント設定の限界である. テス トではMS明朝が用いられ, 形状は異なるが, 使用頻度 の観点では流暢フォントのMS P ゴシックと類似してい る. 文脈依存効果に基づくと, 学習場面に伴う文脈が学 習時とテスト時とで一致しているとパフォーマンスが高 くなるので, それが原因で非流暢性効果が相対的に減衰 した可能性もある.

四点目は読みの速さの測定の限界である。本研究では 学習後に両フォントの読みの速さを測ったので, 測定時 点では馴化が生じていた可能性がある。これは, Table 2 に示すように非流暢フォントの読みの速さと学
習成績との相関が弱かったことからも示唆される.

また, 今後の課題として, 学習方略と非流暢性効果と の関連の検討が挙げられる。本研究では流暢・非流暢 フォント課題を比較しつつ似た情報（例：無意味綴りの カタカナ）をまとめて学習を進めていたという報告が 2件あった. 非流暢フォント課題はほかのリソースを学 習に活用して工夫することを動機づける機能をもってい るのかもしれない. 参加者がとった方略を調査してカテ ゴリー化し，パフォーマンスや学習時間との関連を検討 することで方略の影響を検討できれば，流暢性研究の飛 躍に貢献できるだろう。

\section{引用文献}

Alter, A. L., \& Oppenheimer, D. M. (2009). Uniting the tribes of fluency to form a metacognitive nation. Personality and Social Psychology Review, 13, 219-235.

Besken, M., \& Mulligan, N. W. (2013). Easily perceived, easily remembered?: Perceptual interference produces a double dissociation between metamemory and memory performance. Memory \& Cognition, 41, 897-903.

Bjork, R. A., \& Yue, C. L. (2016). Commentary: Is disfluency desirable? Metacognition Learning, $11,133-137$.

Carpenter, S. K., Wilford, M. M., Kornell, N., \& Mullaney, K. M. (2013). Appearances can be deceiving: Instructor fluency increases perceptions of learning without increasing actual learning. Psychonomic Bulletin \& Review, 20, 1350-1356.

De Bruin, A. B. H., \& Van Gog, T. (2012). Improving self-monitoring and self-regulation: From cognitive psychology to the classroom. Learning and Instruction. 22, 245-252.

Diemand-Yauman, C., Oppenheimer, D. M., \& Vaughan, E. B. (2011). Fortune favors the Effects of disfluency on educational outcomes. Cognition, 118, 114-118.

Dunlosky, J., \& Ariel, R. (2011). Self-regulated learning and the allocation of study time. Psychology of Learning and Motivation, 54, 103-140.

Eitel, A., Kühl, T., Scheiter, K., \& Gerjets, P. (2014). Disfluency meets cognitive load in multimedia learning: Does harder-to-read mean better-to-understand? Applied Cognitive Psychology, 28, 488-501.

Elliot, A. J., \& Harackiewicz, J. M. (1994). Goal setting, achievement orientation, and intrinsic motivation: A mediational analysis. Journal of 
Personality and Social Psychology, 66, 968-980.

French, M. M. J., Blood, A., Bright, N. D., Futak, D., Grohmann, M.J., Hasthorpe, A., ... Tabor, J. (2013). Changing fonts in education: How the benefits vary with ability and dyslexia. The Journal of Educational Research, 106, 301-304.

南風原朝和・平井洋子・杉澤武俊（2009）。心理 統計学ワークブック 理解の確認と深化のため に 有斐閣

市川伸一（1993）。学習を支える認知カウンセリ ング——理学と教育の新たな接点——ブ レーン出版

市村賢士郎・上田祥行・楠見 孝 (2016). 課題 動機づけにおける困難度情報が課題努力に及ぼ す影響 心理学研究, 87, 262-272.

Kornell, N., Rhodes, M. G., Castel, A. D., \& Tauber, S. K. (2011). The ease-of-processing heuristic and the stability bias: Dissociating memory, memory beliefs, and memory judgments. Psychological Science, 22, 787-794.

Kühl, T., \& Eitel, A. (2016). Effects of disfluency on cognitive and metacognitive processes and outcomes. Metacognition Learning, 11, 1-13.

Magreehan, D. A., Serra, M. J., Schwartz, N. H., \& Narciss, S. (2016). Further boundary conditions for the effects of perceptual disfluency on judgments of learning. Metacognition Learning, $11,35-56$.

Marton, F., \& Saljo, R. (2005). Approaches to Learning. In F. Marton, D. Hounsell, \& N. Entwistle (Eds.), The Experience of Learning: Implications for teaching and studying in higher education (3rd (Internet) ed.), (pp. 39-58). Edinburgh: University of Edinburgh, Centre for Teaching, Learning and Assessment.

Metcalfe, J. (2009). Metacognitive judgements and control of study. Current Direction in Psychological Science, 18, 159-163.

宮代こず急・原田悦子（2016）。語義と視覚表現 の意味の一致が単語処理に及ぼす影響—プラ イミング効果による検討——認知科学, 23 , 118-134.

Motyka, S., Suri, R., Grewal, D., \& Kohli, C. (2016). Disfluent vs. fluent price offers: Paradoxical role of processing disfluency. Journal of the Academy of Marketing Science, 44, 627-638.

Papadopoulos, T. C., Spanoudis, G. C., \& Georgiou, G. K. (2016). How is RAN related to reading fluency?: A comprehensive examination of the prominent theoretical accounts.
Frontiers in Psychology, 7, 1-15.

Peirce, J. W. (2007). PsychoPy-Psychophysics software in Python. Journal of Neuroscience Methods, 162, 8-13.

Pieger, E., Mengelkamp, C., \& Bannert, M. (2016). Metacognitive judgments and disfluency: Does disfluency lead to more accurate judgments, better control, and better performance? Learning and Instruction, 44, 31-40.

Pieger, E., Mengelkamp, C., \& Bannert, M. (2017). Fostering analytic metacognitive processes and reducing overconfidence by disfluency: The role of contrast effects. Applied Cognitive Psychology, 31, 291-301.

Rhodes, M. G., \& Castel, A. D. (2009). Metacognitive illusions for auditory information: Effects on monitoring and control. Psychonomic Bulletin \& Review, 16, 550-554.

Rummer, R., Schweppe, J., \& Schwede, A. S. (2016). Fortune is fickle: null-effects of disfluency on learning outcomes. Metacognition Learning, 11, 57-70.

Song, H., \& Schwarz, N. (2008). If it's hard to read, it's hard to do. Psychological Science, 19, 986-988.

Sungkhasettee, V. W., Friedman, M. C., \& Castel, A. D. (2011). Memory and metamemory for inverted words: Illusions of competency and desirable difficulties. Psychonomic Bulletin \& Review, 18, 973-978.

Thiede, K. W., \& Dunlosky, J. (1999). Toward a general model of self-regulated study: An analysis of selection of items for study and self-paced study time. Journal of Experimental Psychology: Learning, Memory, and Cognition, 25, 1024-1037. 梅本堯夫・森川弥寿雄・伊吹昌夫（1955）。清音 2 字音節の無連想価及び有意味度 心理学研 究, 26, 148-155.

梅本貴豊・田中健史朗 (2012). 大学生における 動機づけ調整方略 パーソナリティ研究, 21 , 138-151.

Yue, C. L., Bjork, E. L., \& Bjork, R. A.(2013). Reducing verbal redundancy in multimedia learning: An undesired desirable difficulty? Journal of Educational Psychology, 105, 266-277.

Zimmerman, B. J. (1998). Academic studying and the development of personal skill: A selfregulatory perspective. Educational Psychologist, 33(2/3), 73-86.

（2018年 12 月 9 日受稿， 2020 年 1 月 27 日受理） 